Article

\title{
Interactions between the Hyperaccumulator Noccaea caerulescens and Brassica juncea or Lupinus albus for Phytoextraction
}

\author{
Isabel Martínez-Alcalá ${ }^{D}$, Rafael Clemente *(D) and María Pilar Bernal \\ Department of Soil and Water Conservation and Organic Waste Management, CEBAS-CSIC, \\ Campus Universitario de Espinardo, 30100 Murcia, Spain; immartinezalcala@gmail.com (I.M.-A.); \\ pbernal@cebas.csic.es (M.P.B.) \\ * Correspondence: rclemente@cebas.csic.es
}

Received: 31 July 2020; Accepted: 5 September 2020; Published: 11 September 2020

check for updates

\begin{abstract}
Trace-element-contaminated soils cause environmental concern and represent a source of contamination for surrounding areas. Phytoremediation uses plants to diminish the environmental risks associated with this contamination. When the final aim is the extraction of the pollutants, this technique requires the use of plants that are able to accumulate high concentrations of the target elements in their aerial part, while producing high plant biomass. Here, pot experiments were carried out in order to determine the interaction between a hyperaccumulator (Nocaea caerulescens) and a metal excluder (Lupinus albus) or an accumulator (Brassica juncea) species regarding their trace element accumulation/exclusion capacity when sharing the rhizosphere. The plants were grown alone or were cocultivated in soils with different levels of trace element contamination. The Zn concentration in $N$. caerulescens plants was lower in cocultivation with $B$. juncea than when they were grown alone, indicating competition between the two species for Zn uptake. Contrastingly, when grown with L. albus, the Zn concentrations in N. caerulescens plants were higher than when grown alone. Therefore, under climatic conditions adequate for $N$. caerulescens growth, cocultivation with L. albus could favor Zn phytoextraction, while in the case of $B$. juncea, crop rotation rather than cocultivation is recommended for efficient phytoextraction.
\end{abstract}

Keywords: phytoremediation; trace elements; soil contamination; cocultivation; rhizosphere

\section{Introduction}

Soil pollution by trace elements (TEs; heavy metals and metalloids) is a global environmental problem. In the 1990s, the International Soil Reference and Information Centre (ISRIC) and the United Nations Environment Programme (UNEP) estimated that 22 million hectares of soil are affected by soil pollution [1]. The Food and Agriculture Organization of the United Nations (FAO) was unable to obtain an exact assessment of polluted soil since there were no precise data from low- and middle-income countries [2].

Phytoremediation techniques have been extensively used to remediate various contaminated soils, with good results being obtained for heavy metals and metalloids, radionuclides, and persistent organic pollutants in affected soils [3]. Specific plant characteristics are taken advantage of to remove, degrade, or stabilize different potentially toxic TEs and organic compounds occurring in polluted soils and waters. This gives rise to the techniques of phytoextraction, phytovolatilization, phytodegradation, phytostabilization, and rhizofiltration, among others [4].

Many members of the Brassicaceae family are known to be hyperaccumulators of TEs because they accumulate metals/metalloids in their aboveground tissues without showing any toxicity symptoms [5]. 
Noccaea caerulescens (previously named Thlaspi caerulescens), a member of the Brassicaceae, is the best-documented Zn hyperaccumulator; some lines can also be considered Cd hyperaccumulators [6-8]. Plants of this species can take up and accumulate large amounts of $\mathrm{Zn}$ and $\mathrm{Cd}$ (up to 40,000 $\mu \mathrm{g} \mathrm{g} \mathrm{g}^{-1}$ of $\mathrm{Zn}$ and $380 \mu \mathrm{g} \mathrm{g}^{-1}$ of $\mathrm{Cd}$, on a dry weight basis) in their aboveground parts without showing toxicity symptoms $[9,10]$. In addition, they can tolerate high concentrations of $\mathrm{Ni}[11]$ and $\mathrm{Pb}[12]$ in the xylem sap. However, high concentrations of $\mathrm{Cu}$ in the growing medium reduce $\mathrm{Zn}$ accumulation [13], which can limit the phytoextraction potential of $N$. caerulescens at multicontaminated sites. The scarce aboveground biomass, the slow growth rate, and the shallow root system of $N$. caerulescens are the main constraints on its phytoremediation efficiency [14].

Indian mustard (Brassica juncea), also a member of the Brassicaceae, is a species adapted to the Mediterranean climate [15] and is known for its capacity to bioaccumulate heavy metals such as $\mathrm{Cd}$ ( $>400 \mu \mathrm{g} \mathrm{g}^{-1}$ dry weight in its shoots) [16], $\mathrm{Pb}$ [17], Se [18], or $\mathrm{Zn}, \mathrm{Cr}, \mathrm{Cu}$, and $\mathrm{Au}$ [19]. However, its phytoextraction efficiency is low in pluricontaminated soils [20], probably due to the interaction between the different TEs for their uptake by roots [21]. Nevertheless, this plant species presents several advantages for phytoremediation, such as fast growth, low water requirements, and relatively high biomass production [22].

White lupin (Lupinus albus), a member of the Fabaceae, is adapted to the Mediterranean climate and is tolerant of heavy metals through their exclusion, although it is able to accumulate large amounts of $\mathrm{Mn}$ in its aerial part [23]. This species induces changes in its rhizosphere (iron plaque formation, $\mathrm{pH}$, Eh, water-soluble organic-C) that lead to TE immobilization [23-27]. Additionally, its proteoid roots release chelating agents in root exudates to mobilize soil Fe, Mn, P, and $\mathrm{Zn}$ when these elements are deficient [25].

Plants induce changes in the rhizosphere through the release of exudates, adsorption and desorption of elements, water uptake, and other physicochemical processes [14,28]. These changes can be directed, in the case of hyperaccumulator species, to improve their phytoextraction potential. For example, Wu et al. [29] used a combination of the metal hyperaccumulator plants N. caerulescens and Sedum alfredii and the low-accumulating but highly mycorrhizal-dependent corn (Zea mays) to increase the efficiency of phytoextraction of $\mathrm{Zn}$ from contaminated sewage sludge. Similarly, intercropping oat (Avena sativa) with white lupin (which represented $11 \%$ of the plants) enhanced the mobility of TEs relevant for phytoremediation $(\mathrm{Pb}, \mathrm{Th})$ or phytomining $(\mathrm{La}, \mathrm{Nd}, \mathrm{Sc})$ in a contaminated soil [30]. Gove et al. [31] found that the Cd concentration in Hordeum vulgare increased when grown with $N$. caerulescens, and they also found increased concentrations of $\mathrm{Cd}, \mathrm{Zn}, \mathrm{Cu}, \mathrm{Pb}$, and $\mathrm{Ni}$ in N. caerulescens when grown with $H$. vulgare and Lepidium heterophyllum. They suggested that $N$. caerulescens may alter the conditions in shared rhizospheres, possibly affecting the availability of certain metals to neighboring plants. Nonetheless, studies using cocultivation or intercropping for phytoremediation purposes are scarce.

Therefore, it can be hypothesized that the $\mathrm{Zn}$ accumulation capacity of the hyperaccumulator $N$. caerulescens is affected differently according to whether it shares a rhizosphere with an accumulator or with an excluder species in cocultivation. In the present work, N. caerulescens was cultivated in soils with high TE concentrations and different $\mathrm{pH}$ values, in combination with either the accumulator B. juncea or the excluder L. albus, to study the interaction of these cocultivated plant species regarding its $\mathrm{Zn}$ accumulation, which will ultimately affect the efficiency of phytoremediation.

\section{Materials and Methods}

\subsection{Soil Characteristics}

Two composite soil samples were taken from two different plots within the same site $\left(37^{\circ} 26^{\prime} 21^{\prime \prime} \mathrm{N}\right.$, $06^{\circ} 13^{\prime} 00^{\prime \prime} \mathrm{W}$ ), which had been contaminated as a consequence of the toxic spillage of the Aznalcóllar mine (Seville, Spain) in 1998 [20]. The two soils differed in their $\mathrm{pH}$ and metal concentrations (Table 1), but both were noncalcareous with a loamy texture (19.7\% clay, $34.3 \%$ silt, and $46.0 \%$ sand), and were 
classified as Typic Xerofluvent (American Soil Taxonomy). Phyllosilicates (principally illite and kaolinite) and jarosite were the main minerals found (X-ray diffraction; [20]) in the clay fraction (particles $<2 \mu \mathrm{m}$ in diameter) of the soils. Quartz minerals and feldspars (anorthite, albite) were the main components of the coarser fractions [20]. Soil samples taken at 0-20 cm depth were air-dried, sieved to $<2 \mathrm{~mm}$, and used in the pot experiments.

Table 1. Characteristics of the soils (mean \pm standard error).

\begin{tabular}{|c|c|c|}
\hline & Soil 1 & Soil 2 \\
\hline $\mathrm{pH}$ & $5.02 \pm 0.05$ & $6.00 \pm 0.04$ \\
\hline $\mathrm{EC}\left(\mathrm{dS} \mathrm{m}^{-1}\right)$ & $2.33 \pm 0.00$ & $1.90 \pm 0.01$ \\
\hline $\mathrm{CaCO}_{3}(\%)$ & $<0.5$ & $<0.5$ \\
\hline CEC (cmolc kg $\left.{ }^{-1}\right)$ & $16.0 \pm 0.5$ & $16.0 \pm 0.5$ \\
\hline $\mathrm{OM}(\%)$ & $1.93 \pm 0.09$ & $3.35 \pm 0.12$ \\
\hline TOC $\left(\mathrm{g} \mathrm{kg}^{-1}\right)$ & $11.1 \pm 0.50$ & $19.5 \pm 0.12$ \\
\hline Total-N $\left(\mathrm{g} \mathrm{kg}^{-1}\right)$ & $1.16 \pm 0.10$ & $3.63 \pm 0.02$ \\
\hline $\mathrm{Fe}\left(\mathrm{g} \mathrm{kg}^{-1}\right)$ & $40.5 \pm 0.02$ & $46.2 \pm 0.03$ \\
\hline $\operatorname{Mn}\left(\mu g g^{-1}\right)$ & $1024 \pm 0.05$ & $1377 \pm 44.6$ \\
\hline $\mathrm{Cu}\left(\mu \mathrm{g} \mathrm{g}^{-1}\right)^{1}$ & $196 \pm 4.81$ & $207 \pm 11.2$ \\
\hline $\mathrm{Zn}\left(\mu \mathrm{g} \mathrm{g}^{-1}\right)^{1}$ & $549 \pm 16.0$ & $781 \pm 41.9$ \\
\hline $\mathrm{Cd}\left(\mu \mathrm{g} \mathrm{g}^{-1}\right)^{1}$ & $2.00 \pm 0.00$ & $1.37 \pm 0.00$ \\
\hline $\mathrm{Pb}\left(\mu \mathrm{g} \mathrm{g}^{-1}\right)^{1}$ & $311 \pm 1.04$ & $473 \pm 29.4$ \\
\hline
\end{tabular}

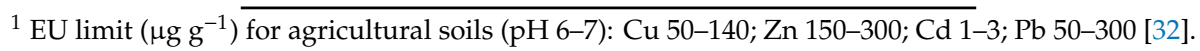

\subsection{Plant Species}

Seeds of N. caerulescens (J. Presl \& C. Presl) F.K. Mey were collected at a metalliferous site (High Tor, Derbyshire, UK) [13], B. juncea L. Czern. cv. 0814-79 seeds were obtained from a germplasm bank collection of Crucifers and provided by Dr. Gómez-Campo (E.T.S.I. Agrónomos Universidad Politécnica, Madrid, Spain) [33], and L. albus L. cv. Marta seeds were acquired commercially.

The seeds were sterilized with $10 \% \mathrm{HClO}$ for $30 \mathrm{~min}$, washed three times with distilled water, and germinated in sand at $28^{\circ} \mathrm{C}$ : for 3 days for L. albus, 4 days for B. juncea, and 16 days for N. caerulescens. Then, the plantlets were transferred to pots (surface area $100 \mathrm{~cm}^{2}$ ) containing $100 \mathrm{~g}$ of sand at the base and $500 \mathrm{~g}$ of soil on top.

\subsection{Experimental Design}

Two experiments were run (Table 2):

Table 2. The different soil/plant combinations used in the experiments.

\begin{tabular}{|c|c|c|}
\hline & Soils & Plants ( ${ }^{\circ}$ of Plants per Pot) \\
\hline \multicolumn{3}{|l|}{ Experiment 1} \\
\hline $\begin{array}{l}\text { D1-Nc } \\
\text { D1-Bj } \\
\text { D1-cocultivation }\end{array}$ & D1: Soil 1 at pH 5.5 & $\begin{array}{c}\text { N. caerulescens }(6) \\
\text { B. juncea (2) } \\
\text { N. caerulescens }(6)+B . \text { juncea (2) }\end{array}$ \\
\hline $\begin{array}{l}\text { D2-Nc } \\
\text { D2-Bj } \\
\text { D2-cocultivation }\end{array}$ & D2: Soil 1 at $\mathrm{pH} 6.4$ & $\begin{array}{c}\text { N. caerulescens (6) } \\
\text { B. juncea }(2) \\
\text { N. caerulescens }(6)+B . \text { juncea }(2)\end{array}$ \\
\hline \multicolumn{3}{|l|}{ Experiment 2} \\
\hline $\begin{array}{l}\text { S1-Nc } \\
\text { S1-La } \\
\text { S1-co-cultivation }\end{array}$ & S1: Soil 1 at $\mathrm{pH} 5.0$ & $\begin{array}{c}\text { N. caerulescens (5) } \\
\text { L. albus (1) } \\
\text { N. caerulescens }(5)+\text { L. albus (1) }\end{array}$ \\
\hline $\begin{array}{l}\text { S2-Nc } \\
\text { S2-La } \\
\text { S2-cocultivation }\end{array}$ & S2: Soil 2 at $\mathrm{pH} 6.1$ & $\begin{array}{c}\text { N. caerulescens }(5) \\
\text { L. albus }(1) \\
\text { N. caerulescens }(5)+\text { L. albus }(1)\end{array}$ \\
\hline
\end{tabular}


Experiment 1. Two plants of B. juncea per pot and six plants of N. caerulescens per pot were grown alone or mixed in the same pot (84 days for N. caerulescens and 70 days for B. juncea) in Soil 1 , with two rates of $\mathrm{CaCO}_{3}\left(1.3\right.$ and $\left.3.0 \mathrm{~g} \mathrm{~kg}^{-1}\right)$ to increase soil $\mathrm{pH}$ to 5.5 (D1) and 6.4 (D2), respectively. The experiment lasted 80 days.

Experiment 2: One plant of L. albus per pot and five plants of $N$. caerulescens per pot were grown alone or mixed in the same pot (168 days for N. caerulescens and 63 days for L. albus) in the two soils (S1 and S2). In this experiment, pots of soil without plants were used as controls. The experiment lasted 105 days.

In Experiment 1, N. caerulescens plantlets were transplanted 14 days before $B$. juncea, while in Experiment 2, N. caerulescens plantlets were transplanted 105 days before L. albus. This was to let the slower-developing N. caerulescens plantlets grow and develop in the pots before planting the second species with greater biomass. Harvesting was performed at the same time for both species. The different biomass expected per pot, according to the species, was the rationale for having different numbers of plants in the two experiments. Different doses of $\mathrm{CaCO}_{3}$ were added to the soil in each experiment to evaluate the influence of soil $\mathrm{pH}$ on the phytoremediation capacity.

Four replicates (pots) were used per treatment in both experiments. The plants were maintained in a growth chamber with a light/dark regime of $16 / 8 \mathrm{~h}$, temperature of $25 / 17^{\circ} \mathrm{C}$ (day/night), and relative humidity of $70 \%$ until harvest. The pots were watered manually every 3-7 days (according to the plants' water requirements) from the bottom of the pot, using tap water. The plants were harvested by cutting the aerial part about $1 \mathrm{~cm}$ above the soil surface and then were washed twice with distilled water and dried at $60^{\circ} \mathrm{C}$ for $48 \mathrm{~h}$. The plant weight and total TE concentrations in the plants were determined. After harvesting, soil from each pot was sampled for chemical analysis by carefully emptying the content of the pots (without taking out the sand at the bottom), homogenizing, removing any visual roots, and collecting samples of at least $100 \mathrm{~g}$. Plant roots were not isolated and analyzed as it was not possible to separate the roots of the different cocultivated plant species.

\subsection{Analytical Procedures}

The soil samples were air-dried, passed through a 2-mm sieve, and homogenized before analysis. Soil $\mathrm{pH}$ was determined in water-saturated pastes using a $\mathrm{pH}$ meter (CRISON BasiC 20), and electrical conductivity (EC) was measured in 1:5 (w/v) soil/water extracts using a conductivity meter (CRISON GLP 31). Total organic C (TOC) and total N (TN) were measured in an automatic microanalyzer (EA3000, EuroVector, Pavia, Italy). Soil pseudototal TEs, after digestion of the soil with aqua regia in a microwave digester (Ethos 1, Milestone Srl, Sorisole, Italy) [34], and $\mathrm{CaCl}_{2}$-extractable metals $\left(0.1 \mathrm{M} \mathrm{CaCl}_{2} 1: 10 \mathrm{w} / v, 16 \mathrm{~h}\right)$ [35] were determined by inductively coupled plasma-optical emission spectrometry (ICP-OES; Iris Intrepid II XDL, Thermo Scientific, Waltham, MA, USA). The analytical accuracy was checked with certified reference material (SRM 2711 Montana Soil). All the concentrations were adjusted to values for oven-dried soil $\left(12 \mathrm{~h}\right.$ at $\left.105^{\circ} \mathrm{C}\right)$.

Aerial biomass production was determined as the fresh and dry $\left(60^{\circ} \mathrm{C}\right.$ for $\left.48 \mathrm{~h}\right)$ weight per pot for each plant species, and heavy metal concentrations in the plant material were determined by ICP-OES after microwave digestion with $\mathrm{H}_{2} \mathrm{O}_{2} / \mathrm{HNO}_{3}(1: 4 v / v)$ [34]. The bioconcentration factor (BCF) was calculated as the concentration of a certain element in the aerial part of the plant with respect to its total concentration in the soil.

\subsection{Statistical Analysis}

Statistical analyses were performed with the software IBM SPSS Statistics Version 24.0 (IBMCorporation, Armonk, NY, USA). The results were subjected to a two-way ANOVA, considering the soil and the cultivation method (each species grown individually or in cocultivation) as factors, and differences between means were determined using Tukey's test. Before the ANOVA, the data were tested for normality using the Kolmogorov-Smirnov test and log-transformed when necessary. The data 
from each plant species in Experiment 2 were evaluated by principal component analysis (PCA) in order to highlight general tendencies.

\section{Results and Discussion}

\subsection{Experiment 1: Noccaea caerulescens and Brassica juncea}

\subsubsection{Plant Growth and Metal Accumulation}

The dry weight of $B$. juncea was significantly higher in soil $\mathrm{D} 2$, with the highest $\mathrm{pH}$ value, than in D1 (Figure 1). Contrastingly, N. caerulescens plants had higher dry weight in the soil of lower $\mathrm{pH}$, D1. For this species, the growth conditions have been reported to be optimal at a $\mathrm{pH}$ value of about 5.1 [36]. However, according to Broadhurst et al. [37], N. caerulescens plants do not exhibit phytotoxicity symptoms over a soil $\mathrm{pH}$ range of 5.5-7.0. In addition, in soil D1, the yield of B. juncea plants was very low, and the determination of their elemental composition was not possible when cocultivated with $N$. caerulescens. In fact, $B$. juncea plants have low survival in soils with $\mathrm{pH}<4$ [20].

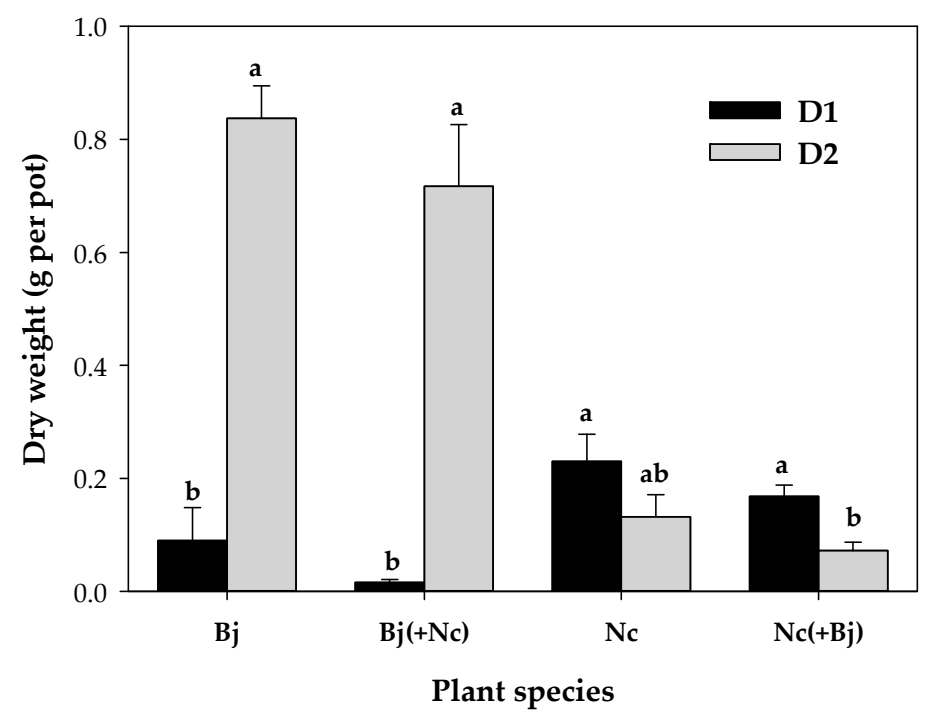

Figure 1. Plant dry weight in the different soils and types of cultivation (g DW $\operatorname{pot}^{-1} \pm$ standard error). For each species, bars marked with different letters indicate significant differences at $p<0.05$, according to Tukey's test. $\mathrm{Bj}=B$. juncea $; \mathrm{Nc}=N$. caerulescens.

The concentrations of Fe found in B. juncea plants, grown in both soils, were similar to those found in other studies (e.g., $91.0 \mu \mathrm{g} \mathrm{g}^{-1}$ ) [38] and generally within the range considered deficient in plants (50-150 $\mathrm{\mu g} \mathrm{g}^{-1}$ ) [39]. This was also the case for N. caerulescens plants grown in D1, while plants from D2 had slightly higher Fe concentrations (Table 3). Interestingly, the Fe concentration found by Walker and Bernal [13] in the same line of N. caerulescens grown in a nutrient solution $\left(103 \mu \mathrm{g} \mathrm{g}^{-1}\right)$ was similar to that found in the present experiment.

The concentrations of $\mathrm{Cu}$ in B. juncea plants grown in D1 were near the threshold considered for plant toxicity of $20 \mu \mathrm{g} \mathrm{g}^{-1}$ [40]. The $\mathrm{Cu}$ concentrations were lower in D2, but not significantly so (Table 3). The highest $\mathrm{Cu}$ concentration in $\mathrm{N}$. caerulescens was $15 \mu \mathrm{g} \mathrm{g}^{-1}$ for plants grown alone in D2. This value is of the same magnitude as that obtained by Walker and Bernal [13] in contaminated soil $\left(7 \mu \mathrm{g} \mathrm{g}^{-1}\right)$ and is in the interval considered normal for plants $\left(5-30 \mu \mathrm{g} \mathrm{g}^{-1}\right)$ [40]; no significant differences were observed between soils D1 and D2 
Table 3. Heavy metal concentrations in the plants from Experiment 1 ( $\left.\mu \mathrm{g} \mathrm{g}^{-1} \mathrm{DW}\right)$, B. juncea (Bj) and N. caerulescens (Nc), grown individually and under cocultivation $(n=4)$.

\begin{tabular}{|c|c|c|c|c|c|c|c|c|c|c|c|}
\hline \multicolumn{2}{|c|}{ Soils } & \multicolumn{2}{|c|}{$\mathrm{Fe}$} & \multicolumn{2}{|c|}{$\mathrm{Cu}$} & \multicolumn{2}{|c|}{ Mn } & \multicolumn{2}{|c|}{$\mathrm{Zn}$} & \multicolumn{2}{|c|}{$\mathrm{Cd}$} \\
\hline & & $\mathbf{B j}$ & Nc & $\mathbf{B j}$ & $\mathrm{Nc}$ & $\mathbf{B j}$ & Nc & $\mathbf{B j}$ & Nc & $\mathbf{B j}$ & $\mathrm{Nc}$ \\
\hline \multirow{2}{*}{ D1 } & Individual & $137 \pm 37$ & $76.9 \pm 2.2 b$ & $18.3 \pm 7.5$ & $5.66 \pm 0.04 a b$ & $61.4 \pm 36.7 \mathrm{a}$ & $11.9 \pm 4.3 \mathrm{ab}$ & $3600 \pm 575 a$ & $6025 \pm 1205 a b$ & $6.22 \pm 0.74$ & $1.09 \pm 0.67 b$ \\
\hline & Cocultivation & - & $88.4 \pm 7.8 \mathrm{~b}$ & - & $4.91 \pm 0.85 \mathrm{ab}$ & - & $20.3 \pm 1.7 \mathrm{a}$ & - & $6814 \pm 808 \mathrm{a}$ & - & $2.06 \pm 1.01 \mathrm{ab}$ \\
\hline \multirow{2}{*}{ D2 } & Individual & $47.7 \pm 3.5$ & $251 \pm 120 \mathrm{a}$ & $10.7 \pm 0.7$ & $14.9 \pm 6.7 \mathrm{a}$ & $16.5 \pm 0.3 b$ & $22.8 \pm 3.4 \mathrm{a}$ & $220 \pm 48 b$ & $6367 \pm 1536 \mathrm{ab}$ & $0.45 \pm 0.45$ & $23.1 \pm 10.2 \mathrm{a}$ \\
\hline & Cocultivation & $98.5 \pm 37.7$ & $133 \pm 5 a b$ & $7.28 \pm 1.26$ & $1.00 \pm 0.57 \mathrm{~b}$ & $16.0 \pm 2.5 b$ & $4.08 \pm 1.82 \mathrm{~b}$ & $210 \pm 53 b$ & $2303 \pm 319 b$ & bdl & $3.66 \pm 1.52 \mathrm{ab}$ \\
\hline \multirow{3}{*}{ ANOVA } & Cultivation & ns & ns & ns & $* *$ & ns & ns & ns & ns & - & ns \\
\hline & Soil & ns & $* *$ & ns & ns & * & ns & $* * *$ & ns & * & $*$ \\
\hline & $\mathrm{CxS}$ & - & ns & - & * & - & $* *$ & - & * & - & ns \\
\hline
\end{tabular}

$\mathrm{ns},{ }^{*}, * *$, and ${ }^{* * *}$ : not significant and significant at $p<0.05,0.01$, and 0.001 , respectively. Values followed by the same letter in each column do not differ significantly according to Tukey's test $(p<0.05)$.bdl = below detection limit. Samples of $B$. juncea grown in D1 under cocultivation were not analyzed due to the low weight obtained. 
The B. juncea plants had their highest concentration of Mn when grown in D1 (Table 3), this value being similar to the results of Feigl et al. [38] $\left(61.4 \mu \mathrm{g} \mathrm{g}^{-1}\right)$. The concentrations of $\mathrm{Mn}$ in cocultivated $N$. caerulescens plants grown in D1 were significantly higher than in soil D2. The values generally were lower than in previous reports for this species in a nutrient solution (e.g., $156 \mathrm{\mu g} \mathrm{g}^{-1}$ [13] and $178 \mu \mathrm{g} \mathrm{g}^{-1}$ [41]), but were similar to the results of McGrath et al. [42] $\left(35.5 \mu \mathrm{g} \mathrm{g}^{-1}\right)$ in contaminated soils.

The concentration of $\mathrm{Zn}$ in B. juncea differed significantly between the soils, with the highest concentrations in soil D1, of low $\mathrm{pH}$. In a field experiment conducted in the area of Aznalcóllar from which our soil samples were taken, high concentrations of $\mathrm{Zn}$ in the aerial part of B. juncea $\left(2029 \mu \mathrm{g} \mathrm{g}^{-1}\right)$ were also observed [20]. Del Rio et al. [15] also found increasing $\mathrm{Zn}$ concentrations in B. juncea plants, from $37.5 \mu \mathrm{g} \mathrm{g}^{-1}$ in uncontaminated soil to $94 \mu \mathrm{g} \mathrm{g}^{-1}$ in soil with $462 \mu \mathrm{g} \mathrm{g}^{-1}$ of total $\mathrm{Zn}$, demonstrating a clear accumulator behavior. BCF found in this species ranged from 0.3 to 6.0 , the latter when $B$. juncea grew alone in D1. This BCF is much higher than that (1.52) found by Ali and Chaudhury [43] in plants grown for 3 months in a noncontaminated soil.

The levels of $\mathrm{Zn}$ in N. caerulescens did not reach hyperaccumulation $\left(10,000 \mu \mathrm{g} \mathrm{g}^{-1}\right)$, neither in soil nor in the growth conditions, perhaps due to the multielemental contamination of the soils (discussed below). The highest concentrations of $\mathrm{Zn}$ in N. caerulescens occurred when grown alone (Table 3), while the lowest values were found in cocultivation with B. juncea in soil D2 (pH 6.4). Zn BCF in the hyperaccumulator was approximately 12 when grown in D1 or alone in D2 but fell to 4.2 when grown with B. juncea in D2. All these BCF values were lower than those found by McGrath et al. [42] in a pot experiment using different contaminated soils. In soil D1, B. juncea plants did not grow well and produced little biomass (Figure 1), a clear symptom of toxicity. Therefore, competition/interaction between B. juncea and N. caerulescens for Zn uptake was not found in this soil.

The results indicate that the presence of $N$. caerulescens did not improve the accumulation of $\mathrm{Zn}$ in the accumulator species (B. juncea). In contrast, the presence of the latter reduced the hyperaccumulating potential (yield and $\mathrm{Zn}$ concentration) of the former, which may indicate competition between the two species for the uptake of nutrients and the bioavailable $\mathrm{Zn}$ fraction in soil D2. The level of $\mathrm{Zn}$ in these soils is not extremely high (although it is greater than the limits for agricultural soils [32]), and $\mathrm{Zn}$ is an essential micronutrient, which is taken up from the same soil fractions by the roots of the hyperaccumulator and other plant species [44]. N. caerulescens is able to bioaccumulate Zn even in soils with low or moderate concentrations [45] due to its highly efficient transport system [46]. According to Whiting et al. [47], the absence of a large-scale active mechanism of $\mathrm{Zn}$ mobilization in the roots of $N$. caerulescens can severely limit the rate of uptake from forms poorly available in the soil and the subsequent accumulation of $\mathrm{Zn}$ in the plant. This may have occurred in the high-pH soil D2, with low $0.1 \mathrm{M} \mathrm{CaCl}_{2}$-extractable concentrations of $\mathrm{Zn}$ (discussed later; Figure 2). Thus, in soil D2, the presence of high-biomass B. juncea plants could have limited the development of the roots of the hyperaccumulator species, preventing them from exploring areas of the soil rich in $\mathrm{Zn}$ that were not dominated by the roots of $B$. juncea. This factor is critical for N. caerulescens to maintain its high accumulation of $\mathrm{Zn}$ [47].

In fact, in soil D2, B. juncea showed a mean Zn phytoextraction value of $121 \mu \mathrm{g} \mathrm{pot}{ }^{-1}$, similar to $N$. caerulescens $\left(174 \mu \mathrm{g} \mathrm{pot}^{-1}\right)$ when grown together. However, N. caerulescens reached the greatest $\mathrm{Zn}$ phytoextraction value when growing alone $\left(1844 \pm 964 \mu \mathrm{g} \mathrm{pot}^{-1}\right)$.

For B. juncea, the concentration of Cd was below the detection limit $\left(0.01 \mu \mathrm{g} \mathrm{g}^{-1}\right)$ when grown combined with the hyperaccumulator species in soil D2, while its maximum $\mathrm{Cd}$ concentration occurred in D1 when grown alone $\left(6.22 \mu \mathrm{g} \mathrm{g}^{-1}\right.$; Table 3). Contrastingly, the Cd concentration in N. caerulescens was highest $\left(23.1 \mu \mathrm{g} \mathrm{g}^{-1}\right)$ when grown alone in $\mathrm{D} 2$, which resulted in a Cd BCF of 11.6, similar to that reported by Martínez-Alcalá et al. [48] for N. caerulescens plants grown in TE-contaminated soil (around 13).

As with $\mathrm{Zn}$, the low biomass of B. juncea in D1 precluded any effect on the Cd uptake by the hyperaccumulator, but its presence in soil $\mathrm{D} 2$ greatly reduced the $\mathrm{Cd}$ concentration in $N$. caerulescens. All the $\mathrm{Cd}$ concentrations found were below the minimum value $\left(100 \mu \mathrm{g} \mathrm{g}^{-1}\right)$ considered to represent 
hyperaccumulation, confirming the report of Walker and Bernal [13] that this line of N. caerulescens is not a Cd hyperaccumulator.

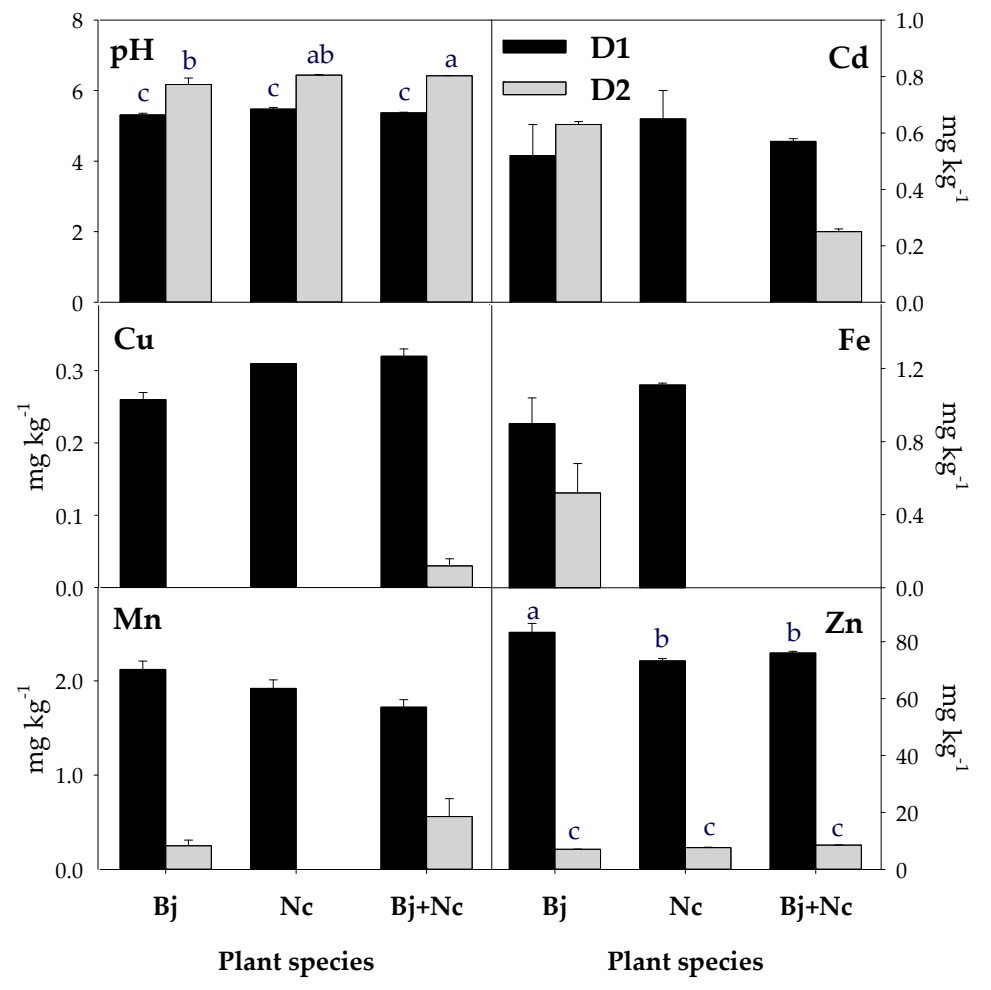

Figure 2. Soil $\mathrm{pH}$ values and concentrations of metals extracted with $0.1 \mathrm{M} \mathrm{CaCl}_{2}$ solution in the soils where B. juncea $(\mathrm{Bj}), N$. caerulescens $(\mathrm{Nc})$, or $B$. juncea and $N$. caerulescens $(\mathrm{Bj}+\mathrm{Nc})$ were grown (mean values (dry soil basis) \pm standard error). For each soil, bars marked with different letters indicate significant differences at $p<0.05$, according to Tukey's test. Bars without letters indicate that statistically significant differences were not found $(p>0.05)$ for the same soil.

\subsubsection{Soil Properties}

The soil $\mathrm{pH}$ values at the end of the experiment were slightly acidic in soil D1, and there was no significant effect of the plant species grown in the soil or of the cocultivation of the two species (Figure 2). Soil D2 showed, as expected, higher $\mathrm{pH}$ values that were, in addition, higher with cocultivation. Kim et al. [49] found that the $\mathrm{pH}$ of the soil solution extracted from the rhizosphere of B. juncea plants was higher than that of the bulk soil solution $(<6.5)$. This effect was not observed in our experiment, as the $\mathrm{pH}$ values did not change compared to the initial values of soils D1 and D2. Although the rhizosphere had not been separated from the bulk soil, the abundance of visually detected roots, which completely covered the soil, could imply a relevant contribution of the rhizosphere in the soil samples. Martínez-Alcalá et al. [48] found no significant changes in the $\mathrm{pH}$ of the rhizosphere of $N$. caerulescens plants, with respect to the bulk soil, in soils with different $\mathrm{pH}$. In fact, the mechanism of metal mobilization by a hyperaccumulator species does not necessarily involve a $\mathrm{pH}$ reduction in the rhizosphere [42,50].

In general, soil D1 had higher concentrations of extractable metals ( $0.1 \mathrm{M} \mathrm{CaCl}_{2}$-extractable) than soil D2 as a consequence of its lower $\mathrm{pH}$ (Figure 2). No significant differences were found between the extractable $\mathrm{Cd}$ concentrations in the soils where B. juncea or $\mathrm{N}$. caerulescens plants were grown, whether in monoculture or together (Figure 2). This was also true for $\mathrm{Cu}, \mathrm{Fe}$, and $\mathrm{Mn}$ in both soils.

The extractable $\mathrm{Zn}$ concentrations in soil D1 were highest when $B$. juncea was grown individually (Figure 2), likely because of the scarce plant biomass of B. juncea (Figure 1) and the strong Zn uptake by $N$. caerulescens (Table 2) in this soil. The uptake of $\mathrm{Zn}$ by the hyperaccumulator species likely first 
involves soluble and exchangeable forms (extractable in $0.1 \mathrm{M} \mathrm{CaCl}_{2}$ ). In fact, active soil mobilization by hyperaccumulator species appears to be less important than their highly active and efficient metal uptake systems $[48,51]$, which results in a depletion of the concentration of highly soluble forms of the metals in the soil. Moreover, the rate of replenishment of soluble forms of $\mathrm{Zn}$ in the soil solution from less labile forms has been found to be slower than the rate of metal uptake by N. caerulescens [52]. Contrastingly, extractable Zn concentrations in soil D2 were much lower than in D1 and were not altered in the soils with $N$. caerulescens with respect to the other species. Hammer and Keller [53] found that EDTA extraction was more suitable to assess the uptake of $\mathrm{Zn}$ by N. caerulescens in acidic soils than extraction with a neutral salt $\left(0.1 \mathrm{M} \mathrm{NaNO}_{3}\right)$, which can only extract the easily soluble $\mathrm{Zn}$ fraction, quickly replaced from less-soluble forms at acidic $\mathrm{pH}$.

\subsubsection{Correlations}

Simple linear correlations between soil and plant parameters for B. juncea and N. caerulescens were calculated. Highly significant negative correlations were found between soil $\mathrm{pH}$ and the extractable concentrations of $\mathrm{Cd}, \mathrm{Cu}, \mathrm{Mn}$, and $\mathrm{Zn}$ in the soil, which confirms that $\mathrm{pH}$ is the key factor influencing the solubility of these metals in the soil (Table 4). Soil $\mathrm{pH}$ was correlated positively with the dry weight of $B$. juncea plants and negatively with the $\mathrm{Cd}$ and $\mathrm{Zn}$ concentrations in this species. Several authors have observed the difficulty of this species to grow in acidic soils [20,54]. Negative correlations between the extractable concentrations of $\mathrm{Cu}, \mathrm{Mn}$, and $\mathrm{Zn}$ and the plant dry weight indicate that high concentrations of these elements in easily available forms may be toxic for B. juncea.

Table 4. Correlation matrix between the soil characteristics and the biomass and metal concentrations of the plants (B. juncea and N. caerulescens) from Experiment 1.

\begin{tabular}{|c|c|c|c|c|c|c|}
\hline & $\mathrm{pH}$ & Dry Weight & $\mathrm{Cu} \mathrm{CaCl} 2$ & $\mathrm{Mn} \mathrm{CaCl}_{2}$ & $\mathrm{Zn} \mathrm{CaCl}_{2}$ & $\mathrm{Cd} \mathrm{CaCl}_{2}$ \\
\hline \multicolumn{7}{|c|}{ B. juncea } \\
\hline $\mathrm{pH}$ & - & $0.867^{* * *}$ & $-0.947^{* * *}$ & $-0.921^{* * *}$ & $-0.966^{* * *}$ & -0.581 * \\
\hline Dry weight & $0.867^{* * *}$ & - & $-0.912^{* *}$ & $-0.931^{* * *}$ & $-0.923^{* * *}$ & ns \\
\hline Cd $d_{\text {plant }}$ & $-0.968^{* * *}$ & $-0.825^{* *}$ & $0.982 * *$ & $0.920 * *$ & $0.974^{* * *}$ & ns \\
\hline $\mathrm{Fe}_{\text {plant }}$ & ns & $-0.783^{* *}$ & ns & ns & ns & ns \\
\hline $\mathrm{Zn}_{\text {plant }}$ & $-0.939^{* *}$ & $-0.919 * * *$ & $0.932 *$ & $0.958^{* * *}$ & $0.957^{* * *}$ & ns \\
\hline \multicolumn{7}{|c|}{ N. caerulescens } \\
\hline $\mathrm{pH}$ & - & -0.675 * & $-0.992^{* * *}$ & $-0.921^{* * *}$ & $-0.997^{* * *}$ & $-0.831^{* *}$ \\
\hline Dry weight & $-0.675 *$ & - & 0.794 * & $0.768^{* *}$ & $0.730 * *$ & $0.860 * * *$ \\
\hline$C d_{\text {plant }}$ & 0.561 * & ns & $-0.726^{*}$ & $-0.763 *$ & ns & ns \\
\hline $\mathrm{Fe}_{\text {plant }}$ & ns & ns & $-0.869 * *$ & $-0.908^{* * *}$ & ns & $-0.839 * *$ \\
\hline $\mathrm{Cu}_{\text {plant }}$ & ns & ns & $0.802 *$ & $0.834^{* *}$ & ns & $0.819^{* *}$ \\
\hline $\mathrm{Mn}_{\text {plant }}$ & ns & ns & 0.787 * & ns & ns & ns \\
\hline $\mathrm{Zn}_{\text {plant }}$ & ns & ns & $0.854^{* *}$ & $0.737^{*}$ & ns & 0.730 * \\
\hline
\end{tabular}

In agreement with this, the $\mathrm{Cd}$ and $\mathrm{Zn}$ concentrations in $\mathrm{B}$. juncea were negatively correlated with plant dry weight. The positive correlation between the concentrations of $\mathrm{Zn}$ in the soil $(0.1 \mathrm{M}$ $\mathrm{CaCl}_{2}$-extractable) and in the plants reflects the $\mathrm{Zn}$ accumulator character of $B$. juncea and its potential to serve as an indicator of $\mathrm{Zn}$ availability in soil [20].

In N. caerulescens, a negative correlation between soil $\mathrm{pH}$ and plant biomass was found (Table 4), which indicates that this species grows better in the slightly acidic soils. As a consequence, plant dry weight was positively correlated with extractable metal concentrations in the soil. The extractable concentrations of $\mathrm{Cu}$ correlated positively with the corresponding concentrations in N. caerulescens, which may indicate that the $\mathrm{Cu}$ concentration in the soils was not high enough to cause toxicity in this species [12], with $\mathrm{Cu}$ acting only as an essential micronutrient. 


\subsection{Experiment 2: Noccaea caerulescens and Lupinus albus}

\subsubsection{Plant Growth and Metal Accumulation}

The L. albus plants showed no significant differences in dry weight (on a per pot basis), whether in monoculture or combined with N. caerulescens (Figure 3). However, this species grew better in soil S2, with higher $\mathrm{pH}$, than in soil S1. Martínez-Alcalá et al. [25] also found that even though L. albus can grow in acid soils, the species performs better in neutral soils. In contrast, N. caerulescens grew better in S1 than in S2, independent of the presence or not of L. albus, in agreement with the well-known preference of this species for soil pH values of 5-6 [36]. The dry weight of the N. caerulescens plants was higher in Experiment 2 than in Experiment 1 due to the longer growing period of the former (an attempt to achieve a plant coverage similar to that of the L. albus plants).

There were no significant differences in the concentrations of $\mathrm{Cd}, \mathrm{Fe}$, or $\mathrm{Mn}$ in L. albus between the two soils or the two cultivation methods (Table 5). The Cd concentrations in L. albus were very low $\left(<1 \mu \mathrm{g} \mathrm{g}^{-1}\right)$, regardless of the soil or cultivation method, indicating an exclusion behavior of this species for this element, which is retained mainly in the roots [55]. Kerley [56] reported similar Fe concentrations in L. albus (80-150 $\mathrm{gg} \mathrm{g}^{-1}$ in the aerial part) grown in a range of soils of different $\mathrm{pH}$. These concentrations are above the Fe sufficiency threshold $\left(50 \mu \mathrm{g} \mathrm{g}^{-1}\right)$ [39].

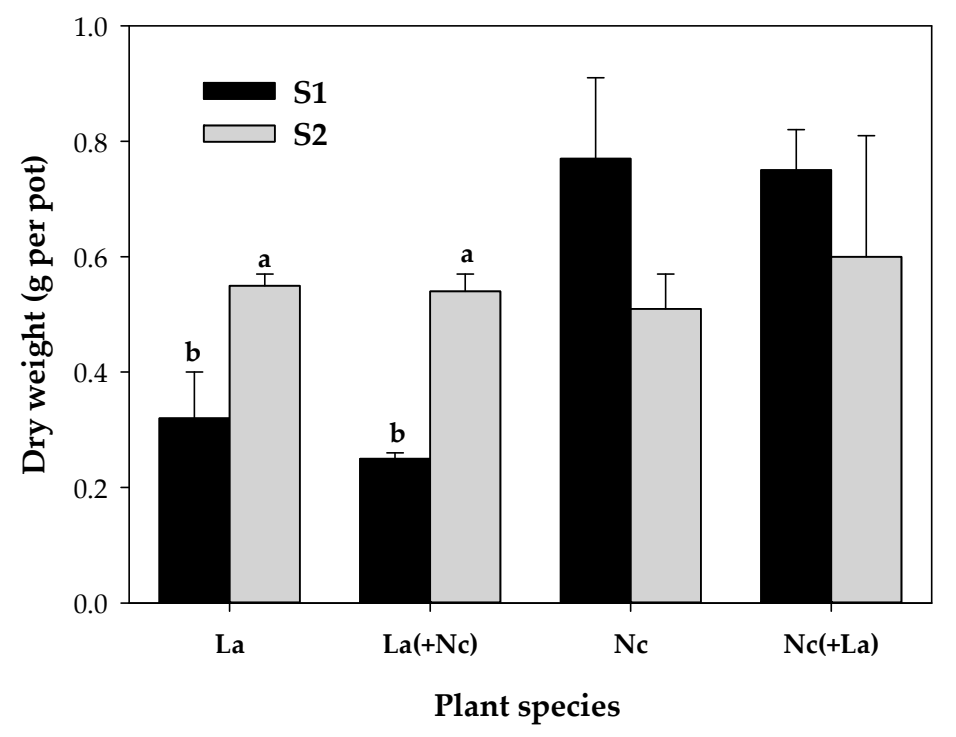

Figure 3. Plant dry weight in the different soils and treatments (g DW $\operatorname{pot}^{-1} \pm$ standard error). For each species, bars marked with different letters indicate significant differences at $p<0.05$, according to Tukey's test. $\mathrm{La}=$ L. albus; $\mathrm{Nc}=N$. caerulescens. Bars without letters indicate that no significant differences were found $(p>0.05)$ between those samples.

The concentrations of $\mathrm{Mn}$ in L. albus ranged from 480 to $783 \mu \mathrm{g} \mathrm{g}^{-1}$, considered normal for this plant species [25], as it can accumulate large amounts of $\mathrm{Mn}$ in its aerial part [25,56]. The Cu concentrations in L. albus were within the same range as those obtained by Martínez-Alcalá et al. [25] in soils of the same area and increased significantly under cocultivation with N. caerulescens (Table 5). The Zn concentrations in L. albus were significantly higher in soil S1 than in soil S2, while only in soil S1 were they significantly higher in cocultivation with $N$. caerulescens than when grown individually (Table 5). The activity of N. caerulescens roots may have induced Zn uptake by L. albus in the most acidic soils, with a high proportion of soluble Zn. However, in a similar experiment, where plants of Thlaspi arvense or Festuca rubra were cocultivated with $N$. caerulescens in a slightly acidic soil containing $150 \mu \mathrm{g} \mathrm{g}^{-1} \mathrm{Zn}$, the hyperaccumulator did not actively mobilize this element and did not promote its uptake by the other plant species [47], as observed in soil S2. 
Table 5. Heavy metal concentrations in the plants (aerial part) from Experiment 2 ( $\left.\mu \mathrm{g} \mathrm{g}^{-1} \mathrm{DW}\right)$, L. albus (La) and N. caerulescens (Nc), under individual cultivation and cocultivation $(\mathrm{n}=4)$.

\begin{tabular}{|c|c|c|c|c|c|c|c|c|c|c|c|}
\hline \multicolumn{2}{|c|}{ Soils } & \multicolumn{2}{|c|}{$\mathrm{Fe}$} & \multicolumn{2}{|c|}{$\mathrm{Cu}$} & \multicolumn{2}{|c|}{ Mn } & \multicolumn{2}{|c|}{$\mathrm{Zn}$} & \multicolumn{2}{|c|}{$\mathrm{Cd}$} \\
\hline & & $\mathbf{L a}$ & Nc & $\mathbf{L a}$ & Nc & La & Nc & La & $\mathrm{Nc}$ & La & $\mathrm{Nc}$ \\
\hline \multirow{2}{*}{ S1 } & Individual & $57.0 \pm 5.3$ & $70.0 \pm 10.8 \mathrm{~b}$ & $6.29 \pm 0.58$ & $8.10 \pm 1.42$ & $480 \pm 44$ & $502 \pm 47 a$ & $437 \pm 18 b$ & $5713 \pm 491 \mathrm{ab}$ & $0.50 \pm 0.06$ & $4.54 \pm 0.45 \mathrm{ab}$ \\
\hline & Cocultivation & $70.3 \pm 14.7$ & $170 \pm 38 \mathrm{ab}$ & $8.54 \pm 0.74$ & $8.58 \pm 0.77$ & $707 \pm 46$ & $543 \pm 19 a$ & $636 \pm 71 \mathrm{a}$ & $7387 \pm 472 \mathrm{a}$ & $0.63 \pm 0.04$ & $5.49 \pm 0.15 \mathrm{a}$ \\
\hline \multirow{2}{*}{ S2 } & Individual & $148 \pm 51$ & $162 \pm 28 \mathrm{ab}$ & $7.29 \pm 0.51$ & $7.96 \pm 1.28$ & $624 \pm 119$ & $281 \pm 58 b$ & $222 \pm 22 c$ & $1998 \pm 310 \mathrm{c}$ & $0.14 \pm 0.08$ & $3.23 \pm 0.31 \mathrm{~b}$ \\
\hline & Cocultivation & $84.8 \pm 15.0$ & $472 \pm 196 \mathrm{a}$ & $8.49 \pm 0.73$ & $7.89 \pm 1.31$ & $783 \pm 179$ & $172 \pm 43 \mathrm{~b}$ & $197 \pm 13 c$ & $4161 \pm 633 \mathrm{~b}$ & $0.69 \pm 0.52$ & $4.97 \pm 0.49 \mathrm{a}$ \\
\hline \multirow{3}{*}{ ANOVA } & Cultivation & ns & * & $*$ & ns & ns & ns & ns & $* *$ & ns & $* *$ \\
\hline & Soil & ns & * & ns & ns & ns & $* * *$ & $* * *$ & $* * *$ & ns & * \\
\hline & $\mathrm{CxS}$ & ns & ns & ns & ns & ns & ns & $*$ & ns & ns & ns \\
\hline
\end{tabular}

$\mathrm{ns},{ }^{*}, * *$, and ${ }^{* * *}$. not significant and significant at $p<0.05,0.01$, and 0.001 , respectively. Values followed by the same letter in each column do not differ significantly according to Tukey's test $(p<0.05)$ 
The concentrations of $\mathrm{Zn}$ in $L$. albus were above the range considered normal for plants (20-150 $\left.\mu \mathrm{g} \mathrm{g}^{-1}\right)$ [40] and, in S1, even exceeded the threshold considered as toxic $\left(300 \mu \mathrm{g} \mathrm{g}^{-1}\right)$ [39], which impaired plant growth (Figure 3). High Zn concentrations were previously found in this species when it was grown in metal-contaminated soils [25].

Plants of N. caerulescens had significantly higher Fe concentrations in soil S2 than in soil S1, and higher concentrations when cocultivated than when grown individually (Table 5). These concentrations are lower than those previously reported for this element in $N$. caerulescens $\left(674 \mu \mathrm{g} \mathrm{g}^{-1}\right)$ [41]. The $\mathrm{Cu}$ concentrations were similarly low in N. caerulescens plants, and there were no significant effects of soil or cultivation type. The Mn concentrations in N. caerulescens were lower than for L. albus and, as expected, were significantly higher in the plants from the soil with the lower $\mathrm{pH}(\mathrm{S} 1, \mathrm{pH} 5.0)$ than in those from soil S2 (pH 6.1).

Uptake and accumulation of $\mathrm{Zn}$ in N. caerulescens were significantly higher in soil S1 and significantly higher in cocultivation with L. albus (Table 5). Lupinus albus has a tolerance mechanism based on metal exclusion and so did not compete with $N$. caerulescens for the uptake of $\mathrm{Zn}$. There was some apparent interaction with L. albus in the rhizosphere that promoted $\mathrm{Zn}$ accumulation in $N$. caerulescens in both soils. The ability of L. albus to produce changes in the rhizosphere (like a decrease in soil $\mathrm{pH}$ or an increase in water-soluble $C$ concentrations) in order to mobilize soil nutrients has been previously tested $[23,25,57]$. In fact, it can develop proteoid roots, on which clusters of rootlets exude chelating agents (organic anions and enzymes such as phosphatase and probably phytase) and hydrogen ions in order to improve the acquisition of nutrients ( $\mathrm{P}, \mathrm{Fe}, \mathrm{Mn}$, and $\mathrm{Zn}$ ) under conditions of deficiency [58]. Dessureault-Rompré et al. [44] suggested that the maintenance of high biological activity in the soil could help to increase the efficiency of metal extraction by hyperaccumulator species. Therefore, the production of root exudates by L. albus and enhanced microbial activity in the rhizosphere [25] may be responsible for the increased accumulation of $\mathrm{Zn}$ in N. caerulescens plants. The calculated BCFs for $\mathrm{Zn}$ in N. caerulescens, when grown in combination with L. albus, were 13.4 and 2.49 for soils S1 and S2, respectively. These values were in a much narrower range than those reported by McGrath et al. [40] (6 to 34) and Robinson et al. [59] (0.3 to 104). These authors utilized soils with higher $\mathrm{pH}$ values and wider $\mathrm{Zn}$ concentration ranges, which may account for the differences from the current results.

The concentrations of $\mathrm{Cd}$ in N. caerulescens were highest with cocultivation in both soils (Table 5), with values of 10-times those of L. albus, but still far below those considered as hyperaccumulation.

\subsubsection{Soil Properties}

No significant differences in soil $\mathrm{pH}$ were produced when L. albus plants grew alone or in combination with $N$. caerulescens in soil S1, nor when grown individually in soil S2, with respect to the control soil without plants (Figure 4). However, in S2, the pH was significantly decreased in the presence of $N$. caerulescens (both alone and cocultivated) compared to the soil with L. albus alone and the control soil, likely as a consequence of the changes in the rhizosphere produced by root exudates $[48,60]$. Similarly, a reduction of 0.2 to $0.3 \mathrm{pH}$ units in the rhizosphere of $N$. caerulescens, with respect to the bulk soil, was previously reported [42], these changes being related to the excess uptake of cations over anions.

The extractable concentrations of Fe in the soils did not vary with the different cultivation methods, and only minor changes were found for $\mathrm{Cu}$ in each soil (Figure 4). The extractable concentrations of $\mathrm{Mn}$ and $\mathrm{Zn}$ were, overall, higher in soil S1 than in soil S2, and only the extractable Zn concentrations in S2 were significantly higher in the soils with $N$. caerulescens (for both individual cultivation and cocultivation) than in the control soil (without plants; Figure 4). The strong uptake of Zn by $N$. caerulescens could have induced its mobilization from less soluble soil fractions through changes in the rhizosphere $[48,52]$, like the observed $\mathrm{pH}$ reduction.

It is noteworthy that the two soils (S1 and S2) with $N$. caerulescens alone showed similar concentrations of extractable $\mathrm{Cd}, \mathrm{Mn}$, and $\mathrm{Zn}$, associated with their similar soil $\mathrm{pH}$ values at the end of the experiment (Figure 4). This effect may also explain why the differences found between the 
cocultivated S1 and S2 soils, regarding the soluble concentrations of $\mathrm{Cd}, \mathrm{Mn}$, and $\mathrm{Zn}$, were smaller than those between the two soils with L. albus cultivated individually.

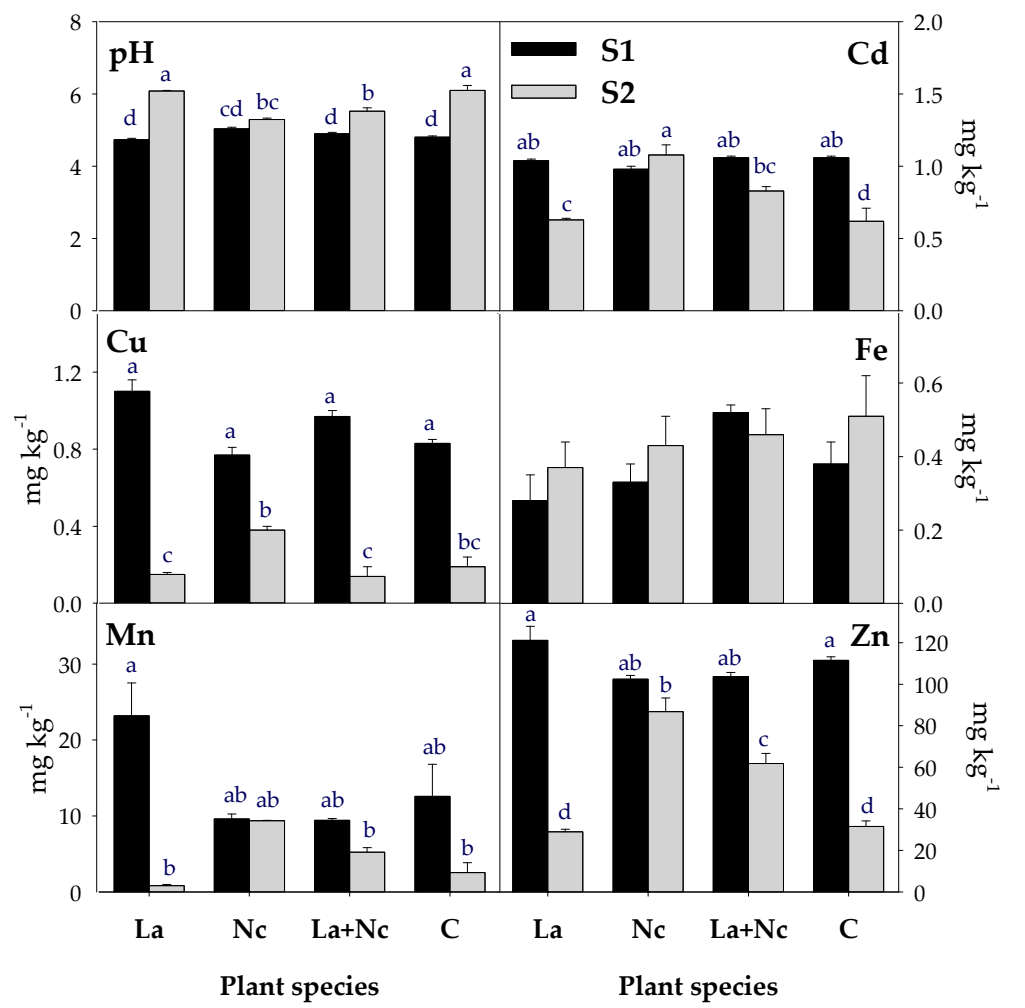

Figure 4. Concentrations of metals extracted with $0.1 \mathrm{M} \mathrm{CaCl}_{2}$ in the soils where L. albus (La), $N$. caerulescens $(\mathrm{Nc})$, or L. albus and N. caerulescens $(\mathrm{La}+\mathrm{Nc}$ ) were grown and in the control (C) soils (with no plants) (mean values (DW) \pm standard error). Bars marked with different letters indicate significant differences at $p<0.05$, according to Tukey's test. Bars without letters indicate that no significant differences were found $(p>0.05)$ between those samples.

\subsubsection{Correlations and Principal Component Analysis (PCA)}

Highly significant negative correlations were found between soil $\mathrm{pH}$ and the extractable concentrations of $\mathrm{Cd}, \mathrm{Cu}, \mathrm{Mn}$, and $\mathrm{Zn}$, which indicates that $\mathrm{pH}$ was key for the solubility of these metals in the soils (Table 6). There were also higher $\mathrm{Zn}$ concentrations in the plants at lower soil pH; this was also observed for $\mathrm{Mn}$ in N. caerulescens.

Table 6. Correlation matrix between the soil characteristics and the biomass and metal concentrations in the plants (L. albus and N. caerulescens) from Experiment 2.

\begin{tabular}{|c|c|c|c|c|c|}
\hline & $\mathrm{pH}$ & $\mathrm{Cu} \mathrm{CaCl} 2$ & $\mathrm{Mn} \mathrm{CaCl}_{2}$ & $\mathrm{Zn} \mathrm{CaCl} 2$ & $\mathrm{Cd} \mathrm{CaCl} 2$ \\
\hline \multicolumn{6}{|c|}{ L.albus } \\
\hline pH & & $-0.905^{* * *}$ & $-0.751 * * *$ & $-0.804^{* * *}$ & $-0.924^{* * *}$ \\
\hline Dry weight & $0.776^{* *}$ & $-0.802^{* * *}$ & ns & $-0.726^{* *}$ & $-0.748^{* *}$ \\
\hline $\mathrm{Fe}_{\text {plant }}$ & $0.570 *$ & ns & ns & ns & ns \\
\hline $\mathrm{Zn}_{\text {plant }}$ & $-0.705^{* *}$ & $0.796^{* * *}$ & ns & $0.726^{* *}$ & $0.787 * *$ \\
\hline \multicolumn{6}{|c|}{ N. caerulescens } \\
\hline $\mathrm{pH}$ & & $-0.854 * * *$ & $-0.715^{* * *}$ & $-0.707^{* * *}$ & $-0.806^{* * *}$ \\
\hline $\mathrm{Fe}_{\text {plant }}$ & $0.679 * *$ & $-0.543 *$ & ns & $-0.515^{*}$ & ns \\
\hline $\mathrm{Mn}_{\text {plant }}$ & $-0743 * *$ & $0.822 * * *$ & 0.763 ** & $0.787 * * *$ & ns \\
\hline $\mathrm{Zn}_{\text {plant }}$ & $-0.711^{* *}$ & $0.741 * *$ & ns & ns & ns \\
\hline
\end{tabular}

$* * *, * *$ and *: significant at $p<0.001,0.01$, and 0.05 , respectively; ns: not significant. 
There was a positive correlation between soil $\mathrm{pH}$ and L. albus dry weight (Table 6), which confirms that this species grows better in soils with a neutral or alkaline $\mathrm{pH}[23,25]$. The extractable concentrations of $\mathrm{Cd}, \mathrm{Cu}$, and $\mathrm{Zn}$ were correlated negatively with L. albus dry weight, which suggests that metal toxicity could have limited the growth of this species in these soils, as indicated by the negative correlation between plant dry weight and $\mathrm{Zn}$ concentration in L. albus $(\mathrm{r}=-0.755, p<0.01)$. The positive correlation of the extractable concentration of $\mathrm{Zn}$ in the soils with the $\mathrm{Zn}$ concentration in L. albus plants suggests the potential for this species to serve as an indicator plant for soil $\mathrm{Zn}$ availability.

For N. caerulescens, soil $\mathrm{pH}$ correlated negatively with the extractable concentrations of $\mathrm{Cd}, \mathrm{Cu}$, $\mathrm{Mn}$, and $\mathrm{Zn}$ in the soil and with the plant $\mathrm{Mn}$ and $\mathrm{Zn}$ concentrations (Table 6). Only for Mn was there a positive correlation between the extractable concentration in the soil and the concentration in the plants. There was no correlation between plant dry weight and any parameter.

All these relationships and effects were confirmed by PCA for L. albus and N. caerulescens (Figure 5). Plant dry weight of L. albus was associated positively with soil $\mathrm{pH}$ (loadings $>0.5$; Table S1, Supplementary Materials) and negatively with the extractable metal concentrations in the soil and the plant $\mathrm{Zn}$ concentration in La-PC1 (51.2\% of the variance). This component clearly separated the soils (Figure S1, Supplementary Materials). The second component showed the relationship between the plant metal concentrations (La-PC2, 27.8\% of the variance) and separated the monoculture from the cocultivation (Figure S1, Supplementary Materials). The PCA for N. caerulescens also related the soil pH and soil extractable-metal concentrations negatively in Nc-PC1 (51.3\% of the variance) and the plant Cd and Zn concentrations positively in Nc-PC2 (17.5\% of the variance). Plant dry weight was negatively related to the $\mathrm{Cu}$ concentration in the N. caerulescens plants in a third component (13.9\% of the variance; Table S2, Supplementary Materials), in agreement with the previously reported sensitivity of this species to this element [13]. The component Nc-PC1 separated soil S1 from S2, while the separation of individually cultivated plants from cocultivated ones was not so evident for this species (Figure S1, Supplementary Materials).
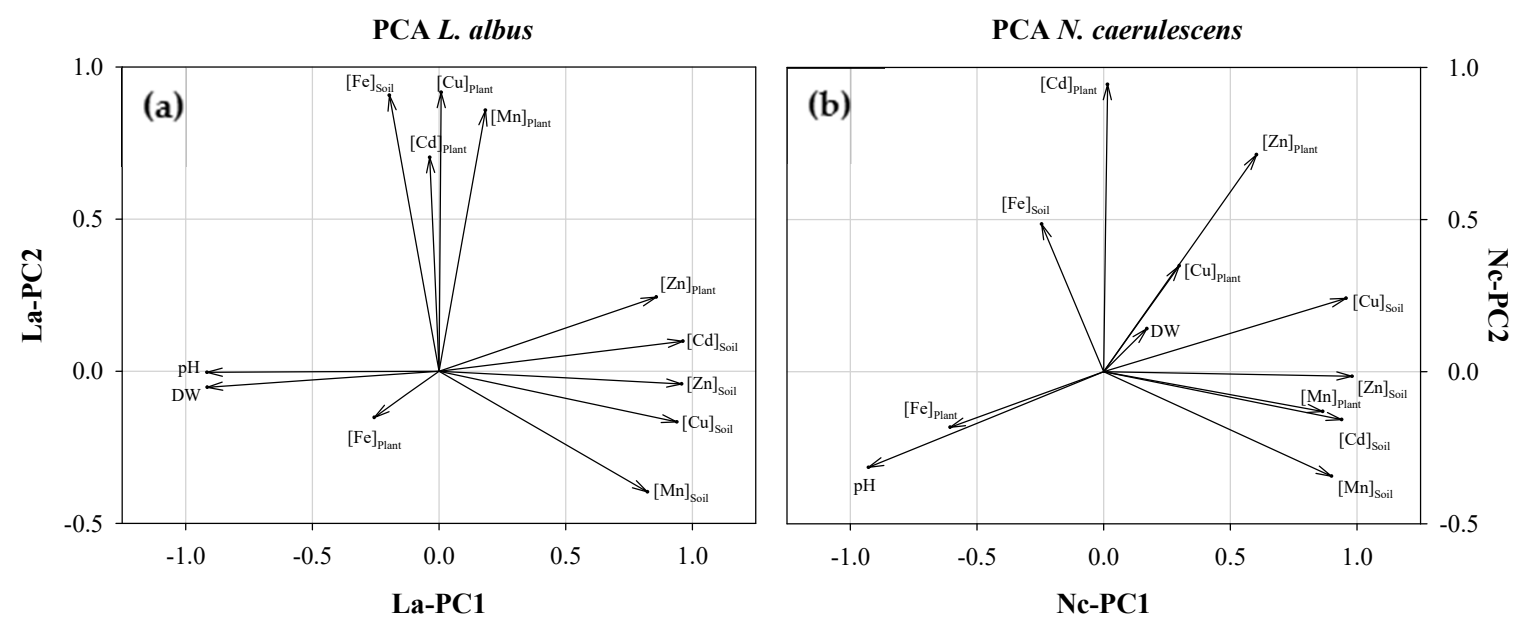

Figure 5. Principal component analysis of the data corresponding to the individual cultivation and cocultivation of L. albus (a) and N. caerulescens (b) plants in Experiment 2.

\section{Conclusions}

The uptake and accumulation of $\mathrm{Zn}$ by N. caerulescens diminished in the presence of B. juncea, especially at circum-neutral soil $\mathrm{pH}$, indicating competition between these species for the uptake of the available $\mathrm{Zn}$ forms in the soil. Nevertheless, the plants of $B$. juncea did not grow well in soils with acid $\mathrm{pH}$ and were sensitive to the soluble metal concentrations in the soil and to high $\mathrm{Cu}$ and $\mathrm{Zn}$ accumulation in the aerial part of the plants. Contrastingly, N. caerulescens grew better in the acid soil than in the circum-neutral one and, generally, was not negatively influenced by the elevated presence of metals in the soil and the plants; the exception was $\mathrm{Cu}$, which is toxic to this species to a 
certain extent, in both experiments. The excluder species L. albus was also negatively affected by low $\mathrm{pH}$ values, high metal availability in the soils, and high $\mathrm{Zn}$ accumulation in the plants, but showed potential as an indicator of $\mathrm{Zn}$ availability. The changes provoked by this species in the root-affected soil apparently favored the accumulation of $\mathrm{Zn}$ in $N$. caerulescens plants when they were cocultivated.

For practical application and extending the results to climatic conditions where $N$. caerulescens can be appropriately cultivated (temperate and medium-high rainfall areas in northern and central Europe), this species may be cocultivated with L. albus for Zn phytoextraction. In the case of B. juncea, alternating cultivation (successive crops or alternate rows) with $N$. caerulescens would be appropriate for $\mathrm{Zn}$ phytoextraction, provided that the relevant agronomic conditions $(\mathrm{pH}$, fertilizer, planting density) are optimized for plant growth and $\mathrm{Zn}$ accumulation and an appropriate $B$. juncea line with high accumulation capacity is selected.

Supplementary Materials: The following are available online at http://www.mdpi.com/2073-4395/10/9/1367/s1. Figure S1: Treatment loadings from the PCAs run with data for each plant species in Experiment 2. Table S1: Results of the PCA run with data for L. albus plants from Experiment 2. Table S2: Results of the PCA run with data for $N$. caerulescens plants from Experiment 2.

Author Contributions: Conceptualization, I.M.-A. and M.P.B.; methodology, I.M.-A. and M.P.B.; formal analysis, I.M.-A.; investigation, I.M.-A., R.C. and M.P.B.; data curation, I.M.-A., R.C., and M.P.B.; writing-original draft preparation, I.M.-A. and M.P.B.; writing-review and editing, R.C. and M.P.B.; supervision, M.P.B.; funding acquisition, R.C. and M.P.B. All authors have read and agreed to the published version of the manuscript.

Funding: This research was funded by the Spanish Ministry of Science and Innovation and the EU (FEDER funds), grant numbers CTM2010-21922-C02-01 and CTM2013-48697-C2-1-R.

Acknowledgments: The authors would like to thank Antonia García-Carrasco for her support in the different experimental and analytical procedures and David J. Walker for the English revision of the manuscript.

Conflicts of Interest: The authors declare no conflict of interest. The funders had no role in the design of the study; in the collection, analyses, or interpretation of data; in the writing of the manuscript, or in the decision to publish the results.

\section{References}

1. Oldeman, L.R.; Hakkeling, R.T.A.; Sombroek, W.G. World Map on Status of Human-Induced Soil Degradation; An Explanatory Note; UNEP/ISRIC: Nairobi, Kenya, 1990; 26p.

2. Rodríguez-Eugenio, N.; McLaughlin, M.; Pennock, D. Soil Pollution: A Hidden Reality; FAO: Rome, Italy, 2018; $142 \mathrm{p}$.

3. Saxena, G.; Purchase, D.; Mulla, S.I.; Saratale, G.D.; Bharagava, R.N. Phytoremediation of heavy metalcontaminated sites: Eco-environmental concerns, field studies, sustainability issues, and future prospects. Rev. Environ. Contam. Toxicol. 2020, 249, 71-131. [CrossRef] [PubMed]

4. Cristaldi, A.; Copat, C.; Conti, G.O.; Zuccarello, P.; Grasso, A.; Ferrante, M. Phytoremediation. In The Handbook of Environmental Remediation: Classic and Modern Techniques; Royal Society of Chemistry: London, UK, 2020; pp. 268-298.

5. Srivastava, N. Phytoremediation of Toxic Metals/Metalloids and Pollutants by Brassicaceae Plants. In The Plant Family Brassicaceae; Springer: Singapore, 2020; pp. 409-435.

6. Assunção, A.G.L.; Bookum, W.M.; Nelissen, H.J.M.; Vooijs, R.; Schat, H.; Ernst, W.H.O. Differential metal-specific tolerance and accumulation patterns among Thlaspi caerulescens populations originating from different soil types. New Phytol. 2003, 159, 411-419. [CrossRef]

7. Gonneau, C.; Noret, N.; Godé, C.; Frérot, H.; Sirguey, C.; Sterckeman, T.; Pauwels, M. Demographic history of the trace metal hyperaccumulator Noccaea caerulescens (J. Presl and C. Presl) F. K. Mey. in Western Europe. Mol. Ecol. 2016, 26, 904-922. [CrossRef] [PubMed]

8. Kozhevnikova, A.D.; Seregin, I.V.; Aarts, M.G.; Schat, H. Intra-specific variation in zinc, cadmium and nickel hypertolerance and hyperaccumulation capacities in Noccaea caerulescens. Plant Soil 2020, 1-20. [CrossRef]

9. Saison, C.; Schwartz, C.; Morel, J.-L. Hyperaccumulation of metals by Thlaspi caerulescens as affected by root development and Cd-Zn/Ca-Mg interactions. Int. J. Phytorem. 2004, 6, 49-61. [CrossRef]

10. Shen, Z.G.; Zhao, F.J.; McGrath, S.P. Uptake and transport of zinc in the hyperaccumulator Thlaspi caerulescens and the non-hyperaccumulator Thlaspi ochroleucum. Plant Cell Environ. 1997, 20, 898-906. [CrossRef] 
11. Mari, S.; Gendre, D.; Pianelli, K.; Ouerdane, L.; Lobinski, R.; Briat, J.F.; Lebrun, M.; Czernic, P. Root-to-shoot long-distance circulation of nicotianamine and nicotianamine-nickel chelates in the metal hyperaccumulator Thlaspi caerulescens. J. Exp. Bot. 2006, 57, 4111-4122. [CrossRef]

12. Baker, A.J.M.; Reeves, R.D.; Hajar, A.S.M. Heavy metal accumulation and tolerance in British populations of the metallophyte Thlaspi caerulescens J. \& C. Presl (Brassicaceae). New Phytol. 1994, 127, 61-68. [CrossRef]

13. Walker, D.J.; Bernal, M.P. The effects of copper and lead on growth and zinc accumulation of Thlaspi caerulescens J. and C. Presl: Implications for phytoremediation of contaminated soils. Water Air Soil Pollut. 2004, 151, 361-372. [CrossRef]

14. Kidd, P.; Barceló, J.; Bernal, M.P.; Navari-Izzo, F.; Poschenrieder, C.; Shilev, S.; Clemente, R.; Monterroso, C. Trace element behaviour at the root-soil interface: Implications in phytoremediation. Environ. Exp. Bot. 2009, 67, 243-259. [CrossRef]

15. Del Rio, M.; Font, R.; Fernandez-Martinez, J.; Domínguez, J.; De Haro, A. Field trials of Brassica carinata and Brassica juncea in polluted soils of the Guadiamar river area. Fres. Environ. Bull. 2000, 9, 328-332.

16. Minglin, L.; Yuxiu, Z.; Tuanyao, C. Identification of genes up-regulated in response to Cd exposure in Brassica juncea L. Gene 2005, 363, 151-158. [CrossRef] [PubMed]

17. Bassegio, C.; Campagnolo, M.A.; Schwantes, D.; Gonçalves Junior, A.C.; Manfrin, J.; Schiller, A.D.P.; Bassegio, D. Growth and accumulation of $\mathrm{Pb}$ by roots and shoots of Brassica juncea L. Int. J. Phytoremediation 2020, 22, 134-139. [CrossRef] [PubMed]

18. Zhang, Z.W.; Dong, Y.Y.; Feng, L.Y.; Deng, Z.L.; Xu, Q.; Tao, Q.; Wang, C.Q.; Chen, Y.E.; Yuan, M.; Yuan, S. Selenium enhances cadmium accumulation capability in two mustard family species-Brassica napus and B. juncea. Plants 2020, 9, 904. [CrossRef]

19. Zhu, Y.L.; Pilon-Smits, E.A.; Tarun, A.S.; Weber, S.U.; Jouanin, L.; Terry, N. Cadmium tolerance and accumulation in Indian mustard is enhanced by overexpressing $\gamma$-glutamylcysteine synthetase. Plant Physiol. 1999, 121, 1169-1177. [CrossRef]

20. Clemente, R.; Walker, D.J.; Bernal, M.P. Uptake of heavy metals and As by Brassica juncea grown in a contaminated soil in Aznalcóllar (Spain): The effect of soil amendments. Environ. Poll. 2005, 138, 46-58. [CrossRef]

21. Kutrowska, A.; Małecka, A.; Piechalak, A.; Masiakowski, W.; Hanć, A.; Barałkiewicz, D.; Andrzejewskac, B.; Zbierskac, J.; Tomaszewska, B. Effects of binary metal combinations on zinc, copper, cadmium and lead uptake and distribution in Brassica juncea. J. Trace El. Med. Biol. 2017, 44, 32-39. [CrossRef]

22. Mourato, M.P.; Moreira, I.N.; Leitão, I.; Pinto, F.R.; Sales, J.R.; Martins, L.L. Effect of heavy metals in plants of the genus Brassica. Int. J. Mol. Sci. 2015, 16, 17975-17998. [CrossRef]

23. Martínez-Alcalá, I.; Clemente, R.; Bernal, M.P. Metal availability and chemical properties in the rhizosphere of Lupinus albus L. growing in a high-metal calcareous soil. Water Air Soil Poll. 2009, 201, 283-293. [CrossRef]

24. Fresno, T.; Peñalosa, J.M.; Santner, J.; Puschenreiter, M.; Prohaska, T.; Moreno-Jiménez, E. Iron plaque formed under aerobic conditions efficiently immobilizes arsenic in Lupinus albus L roots. Environ. Poll. 2016, 216, 215-222. [CrossRef]

25. Martínez-Alcalá, I.; Walker, D.J.; Bernal, M.P. Chemical and biological properties in the rhizosphere of Lupinus albus alter soil heavy metal fractionation. Ecotox. Environ. Saf. 2010, 73, 595-602. [CrossRef] [PubMed]

26. Martínez-Alcalá, I.; Clemente, R.; Bernal, M.P. Efficiency of a phytoimmobilisation strategy for heavy metal contaminated soils using white lupin. J. Geochem. Explor. 2012, 123, 95-100. [CrossRef]

27. Martínez-Alcalá, I.; Hernández, L.E.; Esteban, E.; Walker, D.J.; Bernal, M.P. Responses of Noccaea caerulescens and Lupinus albus in trace elements-contaminated soils. Plant Physiol. Biochem. 2013, 66, 47-55. [CrossRef]

28. Mousavi, S.M.; Motesharezadeh, B.; Hosseini, H.M.; Alikhani, H.; Zolfaghari, A.A. Root-induced changes of $\mathrm{Zn}$ and $\mathrm{Pb}$ dynamics in the rhizosphere of sunflower with different plant growth promoting treatments in a heavily contaminated soil. Ecotox. Environ. Saf. 2018, 147, 206-216. [CrossRef] [PubMed]

29. Wu, Q.T.; Liu, X.M.; Meng, Q.Q.; Long, X.X.; Schwartz, C.; Morel, J.L. Co-crop hyperaccumulator and low-accumulating plants for treating heavy metal contaminated soil and sludge. In Fifth International Conference on Environmental Geochemistry in the Tropics; Institute Soil Science, Chinese Academy of Science: Nanjing, China, 2004; p. 71.

30. Wiche, O.; Székely, B.; Kummer, N.A.; Moschner, C.; Heilmeier, H. Effects of intercropping of oat (Avena sativa L.) with white lupin (Lupinus albus L.) on the mobility of target elements for phytoremediation and phytomining in soil solution. Int. J. Phytorem. 2016, 18, 900-907. [CrossRef] 
31. Gove, B.; Hutchinson, J.J.; Young, S.D.; Craigon, J.; McGrath, S.P. Uptake of metals by plants sharing a rhizosphere with the hyperaccumulator Thlaspi caerulescens. Int. J. Phytorem. 2002, 4, 267-281. [CrossRef]

32. Council of the European Communities. Council directive of 12 June 1986 on the protection of the environment, and in particular of the soil, when sewage sludge is used in agriculture. Official J. Eur. Commun. 1986, L181, 6-12. Available online: http://data.europa.eu/eli/dir/1986/278/oj (accessed on 6 July 2020).

33. Gisbert, C.; Clemente, R.; Navarro-Aviñó, J.; Baixauli, C.; Ginér, A.; Serrano, R.; Walker, D.J.; Bernal, M.P. Tolerance and accumulation of heavy metals by Brassicaceae species grown in contaminated soils from Mediterranean regions of Spain. Environ. Exp. Bot. 2006, 56, 19-27. [CrossRef]

34. U.S. EPA. Method 3051A (SW-846): Microwave Assisted Acid Digestion of Sediments, Sludges, and Oils, Revision 1; U.S. Environmental Protection Agency: Washington, DC, USA, 2007.

35. McGrath, S.P.; Cegarra, J. Chemical extractability of heavy metals during and after long-term applications of sewage sludge to soil. J. Soil Sci. 1992, 43, 313-321. [CrossRef]

36. Yanai, J.; Zhao, F.J.; McGrath, S.P.; Kosaki, T. Effect of soil characteristics on Cd uptake by the hyperaccumulator Thlaspi caerulescens. Environ. Poll. 2006, 139, 167-175. [CrossRef]

37. Broadhurst, C.L.; Chaney, R.L.; Davis, A.P.; Cox, A.; Kumar, K.; Reeves, R.D.; Green, C.E. Growth and cadmium phytoextraction by Swiss chard, maize, rice, Noccaea caerulescens, and Alyssum murale in $\mathrm{pH}$ adjusted biosolids amended soils. Int. J. Phytorem. 2015, 17, 25-39. [CrossRef] [PubMed]

38. Feigl, G.; Kumar, D.; Lehotai, N.; Pető, A.; Molnár, Á.; Rácz, É.; Ördög, A.; Erdei, L.; Kolbert, Z.; Laskay, G. Comparing the effects of excess copper in the leaves of Brassica juncea (L. Czern) and Brassica napus (L.) seedlings: Growth inhibition, oxidative stress and photosynthetic damage. Acta Biol. Hung. 2015, 66, $205-221$. [CrossRef] [PubMed]

39. Marschner, H. Mineral Nutrition of Higher Plants, 2nd ed.; Elsevier Science: San Diego, CA, USA, 1995; 672p.

40. Kabata-Pendias, A. Trace Element in Soil and Plants, 3rd ed.; CRC Press: Boca Raton, FL, USA, 2001; 413p.

41. Molitor, M.; Dechamps, C.; Gruber, W.; Meerts, P. Thlaspi caerulescens on nonmetalliferous soil in Luxembourg: Ecological niche and genetic variation in mineral element composition. New Phytol. 2005, 165, 503-512. [CrossRef] [PubMed]

42. McGrath, S.P.; Shen, Z.G.; Zhao, F.J. Heavy metal uptake and chemical changes in the rhizosphere of Thlaspi caerulescens and Thlaspi ochroleucum grown in contaminated soils. Plant Soil 1997, 188, 153-159. [CrossRef]

43. Ali, S.Y.; Chaudhury, S. EDTA-Enhanced phytoextraction by Tagetes sp. and effect on bioconcentration and translocation of heavy metals. Environ. Process. 2016, 3, 735-746. [CrossRef]

44. Dessureault-Rompré, J.; Luster, J.; Schulin, R.; Tercier-Waeber, M.L.; Nowack, B. Decrease of labile Zn and Cd in the rhizosphere of hyperaccumulating Thlaspi caerulescens with time. Environ. Poll. 2010, 158, 1955-1962. [CrossRef]

45. Baker, A.J.M.; Brooks, R.R. Terrestrial higher plants which hyperaccumulate metallic elements- review of their distribution, ecology and phytochemistry. Biorecovery 1989, 1, 81-126.

46. Clemens, S. How metal hyperaccumulating plants can advance Zn biofortification. Plant Soil 2017, 411, 111-120. [CrossRef]

47. Whiting, S.N.; Leake, J.R.; Mcgrath, S.P.; Baker, A.J.M. Assessment of Zn mobilization in the rhizosphere of Thlaspi caerulescens by bioassay with non-accumulator plants and soil extraction. Plant Soil 2001, 237, 147-156. [CrossRef]

48. Martínez-Alcalá, I.; Bernal, M.P.; de la Fuente, C.; Gondar, D.; Clemente, R. Changes in the heavy metal solubility of two contaminated soils after heavy metals phytoextraction with Noccaea caerulescens. Ecol. Eng. 2016, 89, 56-63. [CrossRef]

49. Kim, K.R.; Owens, G.; Kwon, S.L. Influence of Indian mustard (Brassica juncea) on rhizosphere soil solution chemistry in long-term contaminated soils: A rhizobox study. J. Environ. Sci. 2010, 22, 98-105. [CrossRef]

50. Bernal, M.P.; McGrath, S.P.; Miller, A.J.; Baker, A.J.M. Comparison of the chemical changes in the rhizosphere of the nickel hyperaccumulator Alyssum murale with the non-accumulator Raphanus sativus L. Plant Soil 1994, 164, 251-259. [CrossRef]

51. Lasat, M.M.; Kochian, L.V. Physiology of Zn hyperaccumulation in Thlaspi caerulescens. In Phytoremediation of Contaminated Soil and Water; Terry, N., Bañuelos, G., Eds.; Lewis Publishers: Boca Raton, FL, USA, 2000; pp. 159-169.

52. Puschenreiter, M.; Wieczorek, S.; Horak, O.; Wenzel, W.W. Chemical changes in the rhizosphere of metal hyperaccumulator and excluder Thlaspi species. J. Plant Nut. Soil Sci. 2003, 166, 579-584. [CrossRef] 
53. Hammer, D.; Keller, C. Changes in the rhizosphere of metal-accumulating plants evidenced by chemical extractants. J. Environ. Qual. 2002, 31, 1561-1569. [CrossRef]

54. Fornes, F.; García-de-la-Fuente, R.; Belda, R.M.; Abad, M. 'Alperujo' compost amendment of contaminated calcareous and acidic soils: Effects on growth and trace element uptake by five Brassica species. Bioresour. Technol. 2009, 100, 3982-3990. [CrossRef]

55. Zornoza, P.; Vázquez, S.; Esteban, E.; Fernández-Pascual, M.; Carpena, R. Cadmium-stress in nodulated white lupin: Strategies to avoid toxicity. Plant Physiol. Biochem. 2002, 40, 1003-1009. [CrossRef]

56. Kerley, S.J. Changes in root morphology of white lupin (Lupinus albus L.) and its adaptation to soils with heterogeneous alkaline/acid profiles. Plant Soil 2000, 218, 197-205. [CrossRef]

57. Wu, L.; Kobayashi, Y.; Wasaki, J.; Koyama, H. Organic acid excretion from roots: A plant mechanism for enhancing phosphorus acquisition, enhancing aluminum tolerance, and recruiting beneficial rhizobacteria. Soil Sci. Plant Nutr. 2018, 64, 697-704. [CrossRef]

58. Ryan, P.R.; Delhaize, E.; Jones, D.L. Function and mechanism of organic anion exudation from plant roots. Annu. Rev. Plant Physiol. Plant Mol. Biol. 2001, 52, 527-560. [CrossRef]

59. Robinson, B.H.; Leblanc, M.; Petit, D.; Brooks, R.R.; Kirkman, J.H.; Gregg, P.E. The potential of Thlaspi caerulescens for phytoremediation of contaminated soils. Plant Soil 1998, 203, 47-56. [CrossRef]

60. Puschenreiter, M.; Schnepf, A.; Millán, I.M.; Fitz, W.J.; Horak, O.; Klepp, J.; Schrefl, T.; Lombi, E.; Wenzel, W.W. Changes of Ni biogeochemistry in the rhizosphere of the hyperaccumulator Thlaspi goesingense. Plant Soil 2005, 271, 205-218. [CrossRef]

(C) 2020 by the authors. Licensee MDPI, Basel, Switzerland. This article is an open access article distributed under the terms and conditions of the Creative Commons Attribution (CC BY) license (http://creativecommons.org/licenses/by/4.0/). 